\title{
MODERN CONCEPTS AND VIEWS ON THE PROBLEM OF MALADAPTATION
}

\author{
${ }^{1}$ Kharkiv Medical Academy of Postgraduate Education, \\ ${ }^{2}$ Karazin Kharkiv National University
}

\begin{abstract}
The modern concepts and views of the problem of maladaptation as a psychological phenomenon were analyzed. The main factors influencing the development of this group of disorders were investigated; the definitions and diagnostic criteria were provided in accordance with the fundamental international classifications. Basic symptomatic manifestations as well as key approaches to the therapy were described.
\end{abstract}

Key words: maladaptation, disadaptation of psychological sphere, stress, disorders of adaptation.

Due to the ever-increasing conditions of vital activity, the growth of emotional and informational loads, the increasing demands on the psychological adaptation potential of the individual under conditions of personal-environmental interaction, the need to prevent stressful influences and their consequences for the individual, and to maintain the level of mental and physical health necessary for successful activity the problem of maladaptation is acute.

Peculiarity of personality maladaptation is a negative connotation of its manifestations, which is expressed to a greater or lesser extent and is a consequence of deformation of functioning of psychophysiological, psychological mechanisms that determine a person's state and behavior, its development.

Maladaptation as one pole of the dichotomy «adaptation-maladaptation» is one of the most important characteristics, properties and states of the human body, the subject of personality, which determine the nature of life of the whole personality. The use of the term maladaptation is to some extent ambivalent, which is manifested primarily in the assessment of the role and place of maladaptation states in relation to the categories «norm» and "pathology» [1].

In this regard, the problem of determining the basic characteristics and diagnostic markers of the «psychological vulnerability» of an individual, which is pathogenic soil for the development of maladaptation, including neurotic, stress-related somatoform disorders, exacerbation of procedural mental pathology and personality disorders, is relevant.

A complex multi-level system of organization of human life provides ample opportunities to adapt to changing conditions. The ability to adapt is an integral characteristic of a person, reflects the flexibility and relative stability of his biopsychosocial system. However, stress, especially long-term, can lead to a gradual depletion of adaptation mechanisms and personal resources and, as a result, to a violation of mental adaptation, to disruption of functional systems of vital activity and the development of disorders of varying severity in the mental and somatic sphere $[2,3,4,5]$.

In modern scientific literature on various aspects and problems of adaptation, the following definitions are highlighted: mental adaptation, psychological adaptation, social adaptation, social and psychological adaptation. In this series, mental adaptation plays an important role, largely influencing adaptation processes that take place at various levels. The process of adaptation of human mental activity to the conditions and requirements of the environment is usually called mental adaptation. The organization of the process of mental adaptation, the implementation of interrelations of its main aspects, the regulation of psycho-physiological relationships is implemented by a complex, multi-level functional system, at different levels of which regulation is carried out primarily by psychological (socio-psychological and psychological itself) or physiological mechanisms [4, 5].

The study of mental maladjustment is closely related to the problem of stress. N. Selye, in the framework of his proposed concept of stress, distinguished two levels of an adaptation system. In accordance with his ideas, in a stressful situation, the «superficial» level, which draws its resources from the second, "deep» level, which is "associated" with the adaptation restructuring of the homeostatic systems of the whole organism, reacts first. Moreover, if in conditions of an extreme situation there is a lack of reserves of the "superficial» and delayed mobilization of the «deep» level, then the development of a pathological process is possible, the symptoms of which are nonspecific disorders characteristic of both somatic and mental diseases. Regardless of the type of stress, but in accordance with the phase of adaptation (anxiety, resistance, exhaustion), the formation of an «new functional systematicity of the organism» that meets the requirements of the environment occurs. The 
stressor, regardless of the nature of its origin (biological or social), causes similar non-specific reactions, the specific consequences of which are determined by the individual characteristics of the person. If the load is excessive or social conditions do not allow for an adequate physical response, these processes can lead to physiological and even structural disorders [6].

Studies have shown that mostly not physiological, but the mental level of adaptation is the most sensitive indicator of stress [3]. For a person, stress, as a rule, is an individually perceived phenomenon, the cause of which lies in psychological processes. The state of the organism, resulting from the perception of the situation as unacceptable, negative, rejected while at the same time it is impossible to avoid it, qualifies as emotionally stressful. Physiological manifestations under different types of stress are of the same type, while the set of psychological (emotional, behavioral) manifestations under psychological stress is much more diverse $[7,8]$.

The list of factors that cause stress in a person is diverse, it includes not only physical factors of the external environment, but also information overload due to the continuous increase in the amount of information (the need for accelerated information processing), lack of time, a radical change in social stereotypes and priorities in society caused by country social and economic crises. The psychological and psychosocial factors themselves play a huge role (impossibility of satisfying actual needs, lack of control over events, perceived threat, isolation, group pressure, etc.). Additional sources of stress include impaired physiological functions of the body (as a result of illness, extreme physical exertion and harmful effects of the environment, etc.). Typical stressful events that can lead to disruption of mental adaptation processes include changing lifestyles, increased physical and emotional stress, breaking significant personal relationships, separation from loved ones, changing social status, some types of nosogenic reactions in somatic patients $[7,8,9]$.

Stress is a state of tension that occurs when the adaptive capacity does not match the magnitude of the load acting on a person, causing activation and restructuring of the adaptive resources of the psyche and the body. The degree of stress exposure is largely determined by the nature of the individual experience of the subject, which can both complicate and facilitate an adequate restructuring of behavioral stereotypes; the significance for the individual of those aspects of his relationship with the environment that were violated as a result of the changes that have occurred; the stability of the psycho-physiological relationships and the functional capabilities of the organism.

In the modern sense, the psychological response to a particular stress reagent or stressors that lead to the emergence of clinically meaningful emotional or behavioral manifestations is maladaptation [11]. A maladaptive response to psychosocial stress or stress can be perceived by the subject as a personal misfortune. The adaptation disorder usually ceases shortly after the stress has ceased, or, if stress remains, a new level of adaptation is reached [12].

For clinicians, an important role in the diagnosis of the effects of stressful situations is played by the manifestations of mental maladjustment. The trigger of mental maladaptation, the basis of which is the stress response of the body, is regulation by the principle of feedback. Stress response, covering the entire human body, affects the work of the brain, as well as emotions and behavior.

From the pathogenetic point of view, the stress influence causes in the body a physiological process in the form of corticotropin-releasing factor from the hypothalamus, which stimulates the anterior pituitary to the increased synthesis of adrenocorticotropic hormone (ACTH), which stimulates the stimulation of the corticosteroids. At the same time, due to the activation of the sympathetic nervous system, adrenaline is released from the adrenal medulla into the blood. It is an active stimulator of ACTH secretion by the pituitary gland, which enhances the action of other mechanisms, thereby activating the function of the pituitary gland during stress. Normally, the above processes will soon cease via feedback mechanisms; however, chronic stress effects (even minor ones) against the patient's personality traits, chronic fatigue, previous psychosocial trauma, and other causes will cause prolonged ACTH stimulation and a «breakdown» of the reverse mechanism of inhibition of glucocorticoid secretion. Because of this, a pronounced picture of autonomic dysfunction and mental disorders with the depletion of the adrenal cortex develops [13].

Within the response to the stressful event, several forms of mental maladaptation have been identified with appropriate clinical variants of borderline mental states - from adaptive reactions to severe posttraumatic disorders.

This diagnostic category was first introduced in the third edition of the Manual of Diagnosis and Statistics of Mental Disorders (DSM-III) but is most elaborated in further classifications of diseases. In DSM-IV, they are separated into a separate heading, but are described as psychiatric disorders in the pathogenesis of which emotional stress plays an important role. There is certain "confusion» in terms and terms: the term «stress» means a stressful event, not a universal physiological reaction - a general adaptation syndrome. In DSM-V, adaptive disorders are described as mental, in the pathogenesis of which emotional stress plays an important role: acute stress disorder (308.3); post-traumatic stress disorder (309.81). The 
main difference between acute and post-traumatic stress disorder in the DSM-V is the length of time that has elapsed since the traumatic event. Acute stress disorder is diagnosed between two days and a month after a traumatic incident, and post-traumatic - not earlier than a month, it occurs after an acute stress disorder or latency period, which can last from a few weeks to 6 months, occasionally up to several years [14].

In the international classification of disease $10^{\text {th }}$ revision of the International Statistical Classification of Diseases and Related Health Problems (ICD 10 ), adaptation disorders are distinguished as a separate item (F43.2), sometimes defined as neurotic or adaptive reactions, which are manifested as a state of subjective distress and emotional anxiety, interfere with social functioning and productive activity and arise during the period of adaptation to a significant change in life or a stressful life event. The development of symptoms occurs within one month after exposure to a psycho-social stressor, which is not unusual or associated with a disaster. Symptoms do not continue for more than six months after the cessation of stress or its effects, with the exception of F43.21 (prolonged depressive reaction). Symptoms may be variable in form and severity [15].

For the emergence and development of an adaptation disorder, it is necessary to have an emotional and stressful impact, and the stressful situation should not be extraordinary for a given personality, threaten life, physical and mental well-being. Attempts were made to identify typical stressful events that may lead to disruption of mental adaptation processes. These include a change in lifestyle, increased physical and emotional stress, a break in significant personal relationships, separation from loved ones, a change in social status, and some types of nosogenic reactions in somatic patients $[12,16]$.

The diagnostic criterion under discussion is rather arbitrary, since similar life events have completely different meanings for different people. That is why the second diagnostic criterion of this heading is no less significant - the individual predisposition to the influencing psychogenic with the evidence of the relationship between the action of the stressor and impaired mental adaptation to it $[12,16]$.

The existing diagnostic classifications practically do not discuss the role of the individual in the occurrence and characteristics of the course of adaptation disorders. It does not take into account the experience of overcoming similar situations in history, as well as the sensitizing role of repeated stressful and psychotraumatic influences. In addition, the influence of additional exogenous or somatic hazards, asthenizing factors, organically or somatically altered «soil» is overlooked. The focus of the diagnostic criteria of this rubric is focused on the isolated clinical aspects of adaptation disorders. It indicates the presence of emotional and behavioral disorders, as well as a tendency to commit to a stressful situation and to its dramatization. An important criterion for the diagnosis is the subjective experience of the individual inability to cope with the situation, change it, accept or adapt to it. At the same time, the disturbance of social functioning is expressed in a rough way and, as a rule, manifests itself in a certain decrease in productivity in everyday affairs.

The structure of the clinical picture in different patients may differ significantly, with which the complexity of diagnosis is associated $[17,18]$. In terms of their psychopathological manifestations, adaptation disorders are very variable and, in terms of the difficulty of identifying them, are the diagnostic icebergs [19]. Separate attempts to systematize them with the construction of clinical classifications and the allocation of various options relate to certain social groups: students, military personnel, migrants, single elderly persons [20-23]. Typical options are characterized by the prevalence in the clinical picture of anxious or depressive symptoms or their combination [17, 24]. Clinical forms with a predominance of psycho-vegetative and asthenic disorders, in which hypothymia fades into the background $[17,20]$, are described. In addition, angry, aggressive reactions, behavioral disturbances may dominate in the clinical picture [17, $18,25]$. Insufficiently studied clinical and dynamic aspects of adaptation disorders. According to the existing diagnostic criteria, the duration of adaptation disorders may vary from several months to 2 years. In this case, the criterion of the maximum duration of these states ( 2 years) is quite conditional. In phenomenological terms, this nosographic category remains polymorphic and indefinite. Its boundaries are blurred and cover a whole range of conditions from short-term stress reactions to prolonged psychogenic disorders. In this regard, of particular interest are the works of N. A. Shifner et al. [18], which describe several types of adaptation disorders. The favorable course is characterized by spontaneous or therapeutic regress of psychopathological symptoms and further recovery. With a prolonged type of flow, two options are distinguished: 1) by the type of prolonged maladaptation reactions (from 6 months to 2 years); 2) the type of repetitive cliché reactions that occur after a period of relative normalization of the state. With an unfavorable type of flow, there is a deepening of mental symptoms with the development of other mental disorders: dysthymia, depressive episodes of endogenous or endoreactive structure, nosophobic disorders with the formation of a hypochondriac personality. In general, the term «flow» is not always applicable to this heterogeneous and polymorphic nosographic category. In some cases, this is not about 
the transformation of adaptation disorders into deeper mental disorders, but about an erroneous initial diagnosis. For example, subdepressive episodes, in the development of which psychogenic play a trigger or patoplastic role, may be mistakenly diagnosed at the initial stages as a psychogenic depressive reaction and, thus, fall into the category of "adjustment disorder" [25]. At the same time, in the early stages it is not always possible to conduct an adequate differential diagnosis. The diagnosis of a depressive episode becomes clear only after a long dynamic observation of the patient, when the clinical picture begins to increase the severity of the affective symptoms themselves with endogenomic features. There are other options for adverse outcomes of adaptation disorders, such as high suicidal risk, the development of parasuicidal and self-destructive forms of behavior [26, 27]. An equally important problem is the formation of secondary chemical and non-chemical addictions with protracted variants of adaptation disorders [28]. One of the forms of adaptation disorders, nosogenic (including iatrogenic) reactions that develop in patients with various somatic diseases, have a number of negative medical and social consequences.

The incidence of adaptation disorders in the primary and general medical network exceeds the general population values and reaches $48-52 \%$ [20]. Disorders of adaptation, comorbid somatic disease, significantly complicate its clinical picture, complicate diagnosis and contribute to the formation of refractory and intolerant to standard therapy forms. This leads to deterioration in the prognosis, an increase in the frequency of relapses, and a chronification of the somatic disease. The level of social, family and professional maladjustment of this category of patients is quite high. In general, the likelihood of an unfavorable prediction of an adaptation disorder depends on many factors influencing the ability of an individual to adapt to a change in life or a traumatic event $[7,8,17,18]$. The peculiarities of the psycho-traumatic situation (protracted nature, individual significance), the experience of overcoming similar situations in the past, the psychological characteristics of the patient (character characteristics, skills of problem-solving behavior, self-control, etc.), the nature of the micro-social environment (presence or absence of social support), the presence asthenizing effects (additional load, intoxication, comorbid somatic disease, etc.). An important role is played by timely adequate diagnosis and well-built tactics of complex therapy.

Given the possibility of an adverse course of these disorders, their timely and adequate therapy is a preventive measure for the development of more severe mental pathology. The treatment of such patients should be phased, complex and differentiated depending on the prevailing clinical manifestations. The basic, pathogenetically oriented component is psychotherapy, since psychogenias play a leading role in the development of these disorders [17]. First of all, psychotherapeutic work is aimed at cathartic reaction of negative emotions and increasing the degree of awareness of intrapersonal conflicts that prevent adaptation to the current situation. A necessary stage of the work is to change the patient's attitude towards the stressful (stressful) situation and accept it as part of life experience. It is important to reassess one's own role in a stressful situation, to assume a certain share of responsibility with the formation of an active position in overcoming the prevailing circumstances. In many cases, there is a reconstruction of the entire system of personal relations with a change in the hierarchy of its value-semantic orientations. In the course of psychotherapeutic work, the possibility of expanding the skills of the patient's problem-resolving behavior with their further realization in life appears, his ability to assimilate and regulate negative emotions increases, new strategies of behavior in a stressful situation are developed, and stress tolerance increases.

Conclusions. Selection of pharmacotherapy is always individual and complements the psychotherapeutic work.

Thus, we can draw the following conclusions. the frequency of occurrence of adaptation disorders exceeds the general population values and reaches $48-52 \%$; adaptation disorders have a fairly wide clinical diversity, which depends on the duration of the psycho-traumatic factor; in order to establish the diagnosis of adaptation disorders, a list of basic criteria has been accumulated in world practice: the development of a disorder during the period of adaptation to a significant change in social status or in a stressful life situation; individual vulnerability; the presence of depressive mood, anxiety, anxiety, a feeling of inability to cope with the situation or cope with it, a decrease in social activity in everyday affairs, a tendency towards dramatic behavior, the presence of outbreaks of aggression and negativism; proven relationship between stress and development of the disorder (no more than 3 months); the treatment of such patients should be phased, complex and differentiated depending on the prevailing clinical manifestations. The basic, pathogenetically oriented component is psychotherapy.

\section{List of refeences}

1. Дичев Т. Г. Проблема адаптации и здоровье человека: методологические и социальные аспекты / Т. Г. Дичев, К. Е. Тарасов.- М.: Медичина, 1976.$184 \mathrm{c}$.

2. Медицинская психология и реабилитация: история и современность / Б. Д. Карвасарский, Р. К. Назыров, С. А. Подсадный, Е. И. Чехлатый // 
Психосоциальная реабилитация и качество жизни.СПб., 2001.- С. 203-210.

3. Александровский Ю. А. Состояния психической адаптации и невротические расстройства / Ю. А. Александровский.- М.: ГЭОТАР-Медиа, 2012.- 52 с.

4. Березин Ф. Б. Психическая и психофизиологическая адаптация человека / Ф. Б. Березин.- Л.: Наука, 1988.- 269 c.

5. Вассерман Л. И. Факторы риска психической дезадаптации у педагогов массовых школ: пособ. для врачей и психологов / Л. И. Вассерман, М. А. Беребин.- СПб.: Психоневрол. ин-т, 1997.- 54 с.

6. Селье Г. Стресс без дистресса: пер. с англ. / Г. Селье.- М.: Прогресс, 1982.- 124 с.

7. ІІелестова O. В. Розлади адаптації як наслідок впливу стресу / О. В. Шелестова // Медична психологія.-2016.- № 4.- С. 74-77.

8. Ковров Г. В. Стресс и дезадаптация / Г. В. Ковров, С. Ю. Палатов, М. А. Лебедев // Русс. мед. журн.2010.- № 30.- C. 1859-1863.

9. Kawa $S$. A brief historicity of the diagnostic and statistical manual of mental disorders: issues and implications for the future of psychiatric canon and practice / S. Kawa, J. Giordano // Philos. Ethics. Humanit Med.2012.- Vol. 13 (7).- P. 2.

10. Pierre J. M. The borders of mental disorder in psychiatry and the DSM: past, present, and future / J. M. Pierre // J. Psychiat. Pract. - 2010.- Vol. 16 (6).- P. 375-386

11. Pidchasov E. V. Analysis of socio-psychological manifestations of PTSD in individuals who took part in the fighting / E. V. Pidchasov, G. Lomakin // Extreme problems and crisis psychology. Collected Works. Iss. 10.- Kharkov: NUTSZU, 2011.- P. 86-98.

12. Антипова О. С. Расстройства адаптации: современные подходы к диагностике и терапии / О. С. Антипова // Нейрonews.-2013.- № 3.- C. 29-32.

13. Самойлова O. В. Сучасні погляди на проблему розладів адаптації (огляд наукової літератури) / О. В. Самойлова // Психіатрія, неврологія та медична психологія.- 2018.- № 9.- С. 32-37.

14. Psychosomatic characterization of adjustment disorders in the medical setting: some suggestion for DSM-V / L. Grassi [et al.] // J. Affect Dis. - 2007.- Vol. 101 (1-3).- P. 251-254.

15. Чуркин A. А. Краткое руководство по использованию МКБ-10 в психиатрии и наркологи / А. А. Чуркин, А. Н. Мартюшов.- М.: Триада-Х, 2000.- 232 с.
16. Стресс и расстройства адаптации / Е. С. Акарачкова, О. В. Котова, С. В. Вершинина, И. В. Рябоконь // Лечаший врач.- 2014.- № 6.- С. 61-65.

17. Jounger $M$. Adjustment disorders - nosological state and treatment options / M. Jounger, K. Frasch, T. Becker // Psychiat Prax.-2008. - № 35 (5).- P. 219-225.

18. Ширнер H. А. Клинико-динамическая характеристика расстройств адаптации у студентов / Н. А. Шифнер, А. Е. Бобров, М. А. Кулыгина // Ученые записки.- 2011.- № 18 (4).- С. 64-66.

19. Strain $J . J$. Adjustment disorders: the conundrums of the diagnoses / J. J. Strain, A. Diefenbacher // Comp. Psychiat. - 2008. - № 49 (2).- P. 121-130.

20. Psychosomatic characterization of adjustment disorders in the medical setting: some suggestion for DSM-V / L. Grassi [et al.] // J. Affect. Dis.-2007.- Vol. 101 (1-3). - P. 251-254.

21. Маркова М. В. Дезадаптація волонтерів, діяльність яких пов'язана із забезпеченням військових в зоні бойових дій: механізми формування і психокорекція / М. В. Маркова, С. Ю. Глаголич // Теорія і практика сучасної психології. - 2018. - № 4.- С. 59-69.

22. Lung $F$. $M$. The premorbid personality in military students with adjustment disorders / F. M. Lung, F. E. Lee, B. C. Shu // Military Psychol.-2006.Vol. 18 (1).- P. 77-88.

23. Portzky G. Adjustment disorders and the course of the suicidal process in adolescents / G. Portzky, K. Audenaert, K. van Heeringen // J. Affect. Dis. - 2005. Vol. 87 (2-3).- P. 265-270.

24. American Psychiatric Association. Diagnostic and statistical manual of mental disorders. $4^{\text {th }}$ ed. Text Rev.-Washington DC, 1994; Am. Psychiatric Association Press, 2000.

25. Bronisch $T$. Validity of adjustment disorders comparison with major depression / T. Bronisch, H. Hecht // J. Affect Dis. - 1989. - Vol. 17 (3).- P. 229-236.

26. Portzky G. Adjustment disorders and the course of the suicidal process in adolescents / G. Portzky, K. Audenaert, K. van Heeringen // J. Affect. Dis. - 2005.Vol. 87 (2-3).- P. 265-270.

27. De Leo $D$. Adjustment disorders and suicidality / D. De Leo, C. Pellegrini, L. Serraioto // Psychol. Rep.1986.- Vol. 59.- P. 355-358.

28. Stosberg $K$. Sociological aspects of addictive behavior / K. Stosberg // Offentl. Gesundheitswes. - 1980.Vol. 42 (Suppl. 1).- P. 3-7.

\title{
СУЧАСНІ КОНЦЕПЦІІІ І ПОГЛЯДИ НА ПРОБЛЕМУ ДЕЗАДАПТАЦІІ
}

\author{
M. B. MAPKOBA, M. B. CABIHA
}

Розглянуто основні сучасні концепції та погляди на проблему дезадаптації як психологічного
феномена. Описано основні фактори, що впливають на розвиток цієї групи розладів; наведено
визначення та діагностичні критерії відповідно до основних міжнародних класифікацій хвороб.
Описано базові симптомологічні прояви розладів адаптації, а також основні підходи до їх терапії.

Ключові слова: дезадаптація, психологічна дезадаптивність, стрес, розлади адаптації. 


\title{
СОВРЕМЕННЫЕ КОНЦЕПЦИИ И ВЗГЛЯДЫ НА ПРОБЛЕМУ ДЕЗАДАПТАЦИИ
}

\author{
M. B. MAPKOBA, M. B. CABIHA
}

Рассмотрены основные современные концепции и взгляды на проблему дезадаптации как психологического феномена. Описаны основные факторы, влияющие на развитие данной группы расстройств; приведены определения и диагностические критерии в соответствии с основными международными классификациями болезней. Описаны базовые симптомологические проявления расстройств адаптации, а также основные подходы к их терапии.

Ключевые слова: дезадаптация, психологическая дездаптивность, стресс, расстройства адаптации. 